\title{
Aquí Estamos? A Survey of Latino Portrayal in Introductory U.S. Government and Politics Textbooks
}

Jessica Lavariega Monforti, University of Texas-Pan American

Adam McGlynn, University of Texas-Pan American

ABSTRACT The breadth of material covered in introductory U.S. government and politics survey courses creates a situation in which the textbooks used may serve as the primary source of information students receive about the country's political system. At the same time, their content represents a conscious choice by the authors, editors, and publishers of these textbooks regarding what topics and content are necessary and worthy of publication, which socializes students to accept particular viewpoints of the formation and operation of the U.S. government. Oftentimes, the information presented in textbooks across subdisciplines ignores the political experiences and influence of racial, ethnic, and other minority groups. We test this premise by engaging in a study of 29 introductory U.S. government and politics textbooks to assess the level of coverage and treatment of Latinos/as, the fastest growing racial/ethnic group in the country. We find that the discussion of Latinos in these textbooks is incredibly brief and often limited to the civil rights chapters. Furthermore, Latinos are primarily mentioned in the discussion of immigration, while their overall contributions to the political development of the United States are largely ignored.

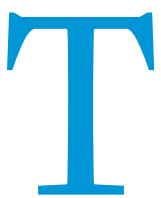

he majority of undergraduate student learning takes place outside of the classroom through course readings, assignments, and research. This is especially true for introductory courses in which faculty must expose students to a sea of information that is both miles wide and deep. Seeking to survey as many topics as possible, faculty often forsake depth of coverage in favor of breadth of topics. Therefore, the introductory textbook takes on a vital role in a student's education. In many cases, the textbook is the primary instructional tool and the source of the majority of student learning (Sleeter and Grant 1991; Tyson-Bernstein 1988; Down

Jessica Lavariega Monforti is an assistant professor of political science and a senior faculty research associate at the Center for Survey Research at the University of TexasPan American. Her research interests center on the politics of race, ethnicity, gender, and immigration. She has recently published work in Social Science Quarterly, the Journal of Women, Politics, \& Policy, and the Latino(a) Research Review. She can be reached atlavariegaj@utpa.edu.

Adam McGlynn is an assistant professor of political science at the University of TexasPan American. His research interests center on public policy, urban politics and Latino politics. He has recently published work in the American Journal of Political Science, Social Science Journal, and Social Science Computer Review. He can be reached at mcglynnaj@utpa.edu.
1988). Textbooks thus become agents of socialization as limited classroom time leads to students taking the majority of what they read in textbooks at face value. The portrayal of people, groups, and events in textbooks serves to mold how students view the world around them and the people with whom they interact.

Nowhere is this truer than in introductory U.S. government textbooks. Because government is the child of politics, we cannot understand one without the other, and the discussion of politics is often colored by one's point of view. In discussing Apple and Christian Smith's (1991) work on the role of politics in textbook creation, Wallace and Allen explain that "race, class, gender/sex and other biases have been widespread in mainstream textbooks, and what is determined as 'legitimate' knowledge does not include the historical experiences of and cultural expressions of labor, women, all racial/ethnic groups, and others who have been denied power" $(2008,153)$. With this idea in mind, we engaged in a survey of the portrayal of Latinos and Latinas in introductory U.S. government and politics textbooks.

In combining the ability of textbooks to socialize students with a relatively nascent political understanding of Latinos, the importance of the point of view of the authors of introductory U.S. 
government and politics textbooks cannot be underestimated. As such, we have undertaken a comprehensive study of these texts to analyze their discussion and treatment of Latinos/as. Although Latino/a politics have been important in urban and border states for many years, the community's national emergence as a political power has been swift, and behind that rapid ascension is a long history of people, groups, and events that have led to the prominent role now held by Latinos/as in U.S. politics. We undertook this study with the idea of exploring whether these books' treatment of Latinos/as is adequate for students to understand and engage this growing and important segment of the U.S. population.

\section{LATINOS/AS' PORTRAYAL IN EDUCATION AND SOCIETY}

At the forefront of the need to accurately discuss and depict Latinos/as in the United States is the continued, dramatic rise in the community's population. Latinos/as accounted for $15 \%$ of the population in 2008 , up from $12.5 \%$ in 2000 , and according to U.S. Census Bureau estimates, the group will double in size to com-
Latinos according to prominent stereotypes, such as "violent, lustful and passive" (Cruz 1994). Carrasquillo (1994) reached a similar conclusion and also cited the need for more Hispanic representation in student instructional materials, because of the prevalence of stereotypes in the materials that attempted to portray Latin culture. Further, in elementary textbooks in which pictures are often more compelling and informative for children, Latinos appear in less than $1 \%$ of pictures included in these works (Cruz 2002). Cruz posits that the lack of coverage of Latinos/as in these textbooks, aside from the much-discussed high Latino dropout rate, may cause these students to "fall victim to a more pernicious type of dropping out-that is, cognitively and affectively disconnecting from school" $(2002,338)$.

Even when there is coverage of Latino/a issues in textbooks, that coverage can often only tell part of the story and may provide an inaccurate description of Latinos/as, as found by Rodriguez and Ruiz (2000) in their study of U.S. history textbooks. They identify one major shortcoming of these texts to be their focus on pan-ethnicity, which sacrifices the discussion of the different his-

\section{Although Latino/a politics have been important in urban and border states for many years, the community's national emergence as a political power has been swift, and behind that rapid ascension is a long history of people, groups, and events that have led to the prominent role now held by Latinos/as in U.S. politics.}

prise $30 \%$ of the population by 2050 . Although we would expect that this increase in population would bring about greater cultural and political awareness among non-Latinos/as regarding Latino/a issues, we observe the exact opposite. For example, despite the academic success of the Tucson Unified School District's (TUSD) Raza Studies program to educate Latino students about their heritage, State Superintendent of Instruction Tom Horne recently pushed the legislature to ban Raza Studies and other similar programs in Arizona schools by withholding $10 \%$ of state funds from districts like TUSD if they continued teaching ethnic studies. Although the proposal died when a vote could not be held before the end of the legislature's session, the bill is expected to be revived next year, easily pass the Republican-dominated state legislature, and be signed by Republican Governor Jan Brewer (Richardson 2009). Arizona is not alone in attempting to revamp its curriculum to dilute the coverage of race and ethnicity. Recently, two members of a Texas State Board of Education group charged with revising the state's social studies curriculum advocated for the removal of César Chávez and Thurgood Marshall, among others, from the curriculum, because they viewed these figures' contributions to the United States as not worthy of inclusion (Torres 2009). Hannan (1987) conveys a grim view of improving curriculum to allow it to better educate multicultural student populations. He cites Hatcher $(1985,45)$, who posits that racism is imbedded into the curriculum and education system partly as result of the ruling class of society's "vested economic and political interest in racism."

Moving to the literature centered on the analysis of instructional materials, other scholars have analyzed the content of $\mathrm{K}-12$ social studies textbooks and found an absence of coverage of Latinos throughout history. Secondary textbooks tend to portray torical experiences of Puerto Ricans as compared to Mexican Americans and Cuban Americans. Because these historical experiences often serve to shape the political opinions, behaviors, and partisanship of these groups (Lavariega Monforti 2006-2007; Lavariega Monforti and García Bedolla 2009), their absence perpetuates misconceptions about the groups in both historical and political contexts.

Normatively, one would hope that in higher education, with its acceptance of diversity of thought and its emphasis on collegiality, we could move past this problem and not segregate the role of Latinos/as in history and politics. However, a recent study conducted by Parks (2007) shows that Latino/a students are still subject to racial discrimination on college campuses. This reality, combined with the lack of Latino/a political scientists (Lavariega Monforti and Michelson 2008), leads us to not expect that collegelevel textbooks will be the panacea for integrating Latinos/as into higher education. Finally, it should be noted that inadequacy in the coverage of Latinos/as extends beyond education to society at large. The National Association of Hispanic Journalists released a "Network Brownout Report" in 2006 that found that out of 12,600 stories reported by nightly network news, less than $1 \%$ dealt exclusively with Latinos/as or Latino/a issues. The severe underrepresentation of Latinos/as in all levels of education and media coverage reaffirms the need for university-level textbooks to provide a thorough and accurate portrayal of the role of Latinos/as in U.S. government and politics. We now turn to the question of whether current textbooks succeed in this endeavor.

\section{METHODOLOGY}

We modeled our analysis on previous works that assessed the treatment and depiction of African Americans (Wallace and Allen 
2008) and lesbians, gays, bisexuals and the transgendered (Novkov and Gossett 2007) in U.S. government and politics textbooks. We selected the most recent editions of 29 texts for analysis, which essentially represent the universe of works currently in circulation. ${ }^{1}$ We then developed a rubric for analyzing the content of these texts, focusing on a set of key terms that would most likely be present in the discussion of Latinos/as. ${ }^{2}$ These terms were classified in three ways: (1) pan-ethnic and country-of-origin identifiers such as Latino/a, Hispanic, Puerto Rican, and Mexican American; (2) important historical figures including but not limited to César Chávez and Dolóres Huerta; and (3) terms and events that could be found in a discussion of the political experience of Latinos/as in the United States, including segregation, immigration, voting rights, and the Civil Rights Movement. For the mention of each term, we conducted a content analysis addressing the following factors:

1. Whether the term is mentioned in the written text or as part of a pictorial

2. Whether the term is discussed in a Latino/a-specific context ${ }^{3}$

3. What chapter mentions the term (e.g., a civil rights chapter)

4. The length of discussion for each mention

5. Whether the term is discussed as part of its own section

6. Whether Latino/as are portrayed in a positive, negative, or neutral fashion.

To conduct this analysis, we searched the index of each text for the key terms listed in our rubric and then reviewed each page of every text to look for appearances not listed in the index, as well as additional Latino/a-specific material not found in the index. Latino/a-specific materials were coded as positive, negative, or neutral based on the context and framework of the overall discussion. For example, in discussing Miranda v. Arizona, one book includes a photo and biography of Ernesto Miranda, explaining that he profited from the case by selling autographed cards printed with Miranda rights, and that he was killed in a bar fight four years after being released from prison (O'Connor et al. 2009). Although this may be factual information, it has no bearing on the substance or outcome of this case. Alternatively, in another textbook, the authors use both written text and a picture to discuss how a 16-year old high school student, Gustavo Jimenez, used text messages and his MySpace page to organize a rally of 3,000 people to oppose a bill that would criminalize being an illegal immigrant. Materials were coded as neutral when unbiased, pertinent, and factual information was presented that would not predispose readers to formulate positive or negative opinions about the information or the group. For example, many textbooks provide tables and charts about the number of Latinos serving in Congress or other elected offices. Following Wallace and Allen (2008), our goal was not to recommend textbooks to our audience, but to craft an accurate description of the treatment and portrayal of the fastest-growing ethnic group in the country in the hope that this information could be used to make the textbooks that millions of undergraduate students purchase more inclusive and representative of the U.S. polity.

\section{RESULTS AND ANALYSES}

Table 1 presents the location of the Latino/a-specific coverage found in each textbook. Here we find that in the majority of the textbooks analyzed, most of the Latino/a-specific coverage is rel- egated to civil rights chapters. This organization is a major shortcoming of most introductory textbooks, because it demonstrates a failure to view Latinos/as as a fully integrated part of the U.S. political system. This is not to say that the movement to secure equal rights for Latinos is unimportant, but the separation of Latino/a-specific coverage conveys the message that the group is a nonentity in other facets of government and politics such as policymaking and the courts. ${ }^{4}$ Table 1 also presents the percentage of a textbook's pages that is dedicated to Latino/a-specific content. We found that 20 of the textbooks analyzed focused less than $1 \%$ of their pages on Latinos, with a maximum percentage found of $3.49 \%$. Quite simply, for the fastest-growing ethnic group in this country, this is a woefully small number. The last column in table 1 provides an evaluation of the sum total of all Latino/a-specific references in each textbook by assigning a point value to each Latino/a-specific mention or reference ( $1=$ negative, $2=$ neutral, $3=$ positive) and then averaging all of the scores. Scores less than 2 indicate that the overall coverage of Latinos in the textbook has a negative slant, and scores above 2 signify a positive slant; the scores ranged from o to 2.75, with an average of 1.97.

Table 2 presents the prevalence of key terms, people, and events in textbooks, and the findings are similarly disappointing. Not surprisingly, immigration is the most common point of reference when discussing Latinos/as, meaning that students will walk away from introductory U.S. government textbooks viewing Latinos primarily as immigrants and, in many cases, illegal immigrants, rather than politically active and important citizens. In many cases, the context of the discussion of Latino immigrants is negative.

Although many of the texts discuss César Chávez, only three mention the contributions of Dolóres Huerta to the Chicano Civil Rights Movement. As well, only three books use or discuss the words Chicano or Brown Power. Nevertheless, the majority of these references are positive. We found that almost all of the textbooks portray Latino/a civil rights as a few random events, and not as part of an overall movement. Major events and players in this movement, including the Los Angeles school walkouts, the Voting Rights Act of 1975, the Raza Unida Party, the Mexican American Legal Defense and Education Fund (MALDEF), the Puerto Rican Legal Defense and Education Fund (PRLDEF), and the League of United Latin American Citizens (LULAC), receive only token mentions, if they are mentioned at all. Furthermore, there is limited discussion of national-origin groups, reinforcing the phenomenon discussed previously that the use of pan-ethnic identifiers dominates the discussion of Latinos/as, fostering the belief that all Latinos/as are created equal and forsaking the importance of national origin in Latino/a political history, ideology, and behavior.

Table 2 also provides an evaluation of the coverage of specific key terms mentioned in each textbook, employing the same positive/neutral/negative scoring system used in table 1 . Table 2 shows that immigration and the use of pan-ethnic identifiers are the most common frames through which Latinos/as are discussed in the textbooks surveyed. Our results show that 14 of the books portray Latinos/as in a negative fashion in the discussion of immigration and 12 books refer to pan-ethnic identifiers with an overall negative connotation.

\section{CONCLUSION AND DISCUSSION}

The discussion of Latinos/as is limited to an extremely small percentage of the materials covered in all of the U.S. government and 
Table 1

Coverage of Latinos in Civil Rights vs. Non-Civil Rights Chapters in Textbooks, 2006-2010

\begin{tabular}{|c|c|c|c|c|c|}
\hline $\begin{array}{l}\text { TEXTBOOKS LISTED } \\
\text { BY LAST NAME } \\
\text { OF FIRST AUTHOR }{ }^{5}\end{array}$ & $\begin{array}{l}\text { TOTAL PAGES WITH } \\
\text { LATINO-SPECIFIC } \\
\text { REFERENCES OUTSIDE OF } \\
\text { CIVIL RIGHTS CHAPTERS }\end{array}$ & $\begin{array}{l}\text { TOTAL PAGES WITH } \\
\text { LATINO-SPECIFIC } \\
\text { REFERENCES IN } \\
\text { CIVIL RIGHTS CHAPTERS }\end{array}$ & $\begin{array}{c}\text { DIFFERENCE BETWEEN } \\
\text { CIVIL RIGHTS AND } \\
\text { NON-CIVIL RIGHTS CHAPTERS }\end{array}$ & $\begin{array}{l}\text { PERCENT OF OVERALL } \\
\text { LATINO-SPECIFIC } \\
\text { PAGES IN TEXTBOOK }\end{array}$ & RATING \\
\hline Barbour and Wright & 1.15 & 4.7 & -3.55 & 0.64 & 2.04 \\
\hline Berman and Murphy & 3.15 & 3.55 & -0.4 & 1.13 & 2.75 \\
\hline Bond et al. & 1.05 & 4.1 & -3.05 & 0.85 & 2.00 \\
\hline Coleman et al. & 0.05 & 0.1 & -0.05 & 0.02 & 2.00 \\
\hline Dautrich et al. & 2.35 & 5.8 & -3.45 & 1.46 & 2.14 \\
\hline Dye et al. & 16.4 & 6.35 & 10.05 & 3.49 & 2.29 \\
\hline Dye and Zeigler & 0 & 0 & 0 & 0.00 & 0.00 \\
\hline Edwards et al. & 1 & 2 & -1 & 0.43 & 2.15 \\
\hline Fiorina et al. & 1.05 & 1.25 & -0.2 & 0.50 & 2.00 \\
\hline Ginsburg et al. & 2.55 & 0.2 & 2.35 & 0.57 & 1.70 \\
\hline Ginsburg et al. (Spitzer)** & 0.25 & 1.5 & -1.25 & 0.37 & 2.14 \\
\hline Greenberg and Page & 1.6 & 0.05 & 1.55 & 0.36 & 1.92 \\
\hline Harrison et al. & 1.25 & 3.65 & -2.4 & 0.76 & 2.11 \\
\hline Janda et al. & 3.95 & 1.6 & 2.35 & 0.86 & 2.13 \\
\hline Katznelson et al.* & 0.25 & 0 & 0.25 & 0.08 & 1.00 \\
\hline Kernell et al. & 1.35 & 1.9 & -0.55 & 0.45 & 2.12 \\
\hline Losco and Baker & 1.75 & 5.85 & -4.1 & 1.85 & 2.23 \\
\hline Lowi et al.** & 1.3 & 0.5 & 0.8 & 0.25 & 1.75 \\
\hline Magleby and Light & 1.95 & 2.6 & -0.65 & 0.80 & 2.40 \\
\hline Miroff et al. ${ }^{* *}$ & 1.65 & 0 & 1.65 & 0.29 & 2.17 \\
\hline O'Connor et al. & 8.65 & 10.25 & -1.6 & 2.68 & 1.93 \\
\hline Patterson and Halter & 1.1 & 4.3 & -3.2 & 1.14 & 2.32 \\
\hline Schmidt et al. & 0.05 & 4.75 & -4.7 & 0.72 & 1.50 \\
\hline Shea et al & 5 & 2.6 & 2.4 & 1.17 & 2.32 \\
\hline Sidlow and Henschen & 0.15 & 6.25 & -6.1 & 1.58 & 2.00 \\
\hline Tannahill & 2.95 & 0.5 & 2.45 & 0.84 & 2.00 \\
\hline Volkomer & 3.5 & 0.1 & 3.4 & 0.97 & 2.00 \\
\hline Welch et al. & 3.3 & 11.9 & -8.6 & 2.58 & 2.06 \\
\hline Wilson and Dilulio & 2.45 & 0.1 & 2.35 & 0.53 & 1.95 \\
\hline
\end{tabular}

* Indicates that the book does not have a civil rights chapter.

** Indicates that the book combines civil liberties and civil rights into the same chapter.

Note: Ratings indicate whether the coverage of Latinos/as has a negative or positive frame (scores less than 2 indicate a negative slant to the overall coverage of Latinos/as; scores above 2 signify a positive slant).

politics textbooks surveyed. Very few of the textbooks in this study mention the Brown Power or Chicano Civil Rights Movement. Discussion of the history of sociopolitical segregation of Latinos across country-of-origin groups is basically nonexistent, and the progress and contributions made in the United States by both U.S.- and foreign-born Latinos is ignored. Additionally, discussion tends to be confined to the civil rights chapters, leaving many students with the impression that Latinos/as are not a significant group in U.S. government and politics more broadly. Although there may be some faculty members who take it upon themselves to correct these omissions and negative biases, we expect that many are not trained in this subfield of the discipline.
Lastly, and maybe most troubling, is that immigration is the most common topic discussed in reference to Latinos/as, and that half of the textbooks we analyzed portray immigration and immigrants negatively. Textbook authors and publishers must address this situation and work to remedy it. Election and population data show that Latinos/as have and will continue to play a fundamental role in our political system. The discussion of Latinos/as should be pervasive in textbooks by addressing their role in institutions and elections, as well as offering the traditional discourse in civil rights chapters. To continue to segregate and minimize the discussion of Latinos/as in our textbooks does a disservice to our discipline and our students. 
Table 2

Summary of Select Latino/a Key Word Use and Frame in Textbooks, 2006-2010

\begin{tabular}{|c|c|c|c|c|c|c|c|}
\hline TEXTBOOKS ${ }^{6}$ & $\begin{array}{l}\text { CÉSAR } \\
\text { CHÁVEZ }\end{array}$ & $\begin{array}{l}\text { DOLÓRES } \\
\text { HUERTA }\end{array}$ & IMMIGRATION & $\begin{array}{l}\text { HISPANIC AMERICAN, } \\
\text { LATINO/A, HISPANIC }\end{array}$ & $\begin{array}{l}\text { NATIONAL-ORIGIN } \\
\text { GROUPS }\end{array}$ & $\begin{array}{c}\text { CHICANO/BROWN } \\
\text { POWER }\end{array}$ & $\begin{array}{l}\text { ELECTED AND } \\
\text { APPOINTED } \\
\text { OFFICIALS }\end{array}$ \\
\hline \multirow[t]{2}{*}{ Barbour and Wright } & 5 & 0 & 34 & 24 & 9 & 0 & 7 \\
\hline & (2.2) & & (1.03) & (2) & (2) & & (2.1) \\
\hline \multirow[t]{2}{*}{ Berman and Murphy } & 2 & 0 & 0 & 2 & 0 & 0 & 3 \\
\hline & (3) & & & (2.5) & & & (2) \\
\hline \multirow[t]{2}{*}{ Bond et al. } & 0 & 0 & 4 & 10 & 1 & 0 & 0 \\
\hline & & & (1.25) & (1.8) & (3) & & \\
\hline \multirow[t]{2}{*}{ Coleman et al. } & 0 & 0 & 7 & 11 & 1 & 0 & 2 \\
\hline & & & (2) & (2) & (2) & & (1.5) \\
\hline \multirow[t]{2}{*}{ Dautrich et al. } & 0 & 0 & 15 & 8 & 2 & 0 & 2 \\
\hline & & & $(2.07)$ & (2.13) & (2) & & (3) \\
\hline \multirow[t]{2}{*}{ Dye et al. } & 1 & 0 & 5 & 8 & 5 & 0 & 2 \\
\hline & (3) & & (2) & (2.13) & (2) & & (2) \\
\hline \multirow[t]{2}{*}{ Dye and Zeigler } & 0 & 0 & 5 & 3 & 0 & 0 & 0 \\
\hline & & & $(1.60)$ & (2) & & & \\
\hline \multirow[t]{2}{*}{ Edwards et al. } & 1 & 0 & 27 & 19 & 2 & 0 & 3 \\
\hline & (2) & & (1.96) & $(2.11)$ & (2) & & (2) \\
\hline \multirow[t]{2}{*}{ Fiorina et al. } & 0 & 0 & 8 & 3 & 2 & 0 & 0 \\
\hline & & & (2.25) & (1.67) & (2) & & \\
\hline \multirow[t]{2}{*}{ Ginsburg et al. } & 0 & 0 & 6 & 12 & 0 & 0 & 5 \\
\hline & & & (1.67) & $(2.08)$ & & & (1.8) \\
\hline \multirow[t]{2}{*}{ Ginsburg et al. (Spitzer) } & 0 & 0 & 2 & 3 & 0 & 0 & 2 \\
\hline & & & (2) & (2) & & & (1) \\
\hline \multirow[t]{2}{*}{ Greenberg and Page } & 0 & 0 & 2 & 13 & 1 & 0 & 2 \\
\hline & & & (2) & (1.92) & (2) & & (2) \\
\hline \multirow[t]{2}{*}{ Harrison et al. } & 2 & 1 & 23 & 23 & 5 & 1 & 2 \\
\hline & (2.5) & (2) & $(1.87)$ & (2) & (2.2) & (3) & (1.5) \\
\hline \multirow[t]{2}{*}{ Janda et al. } & 2 & 0 & 12 & 13 & 2 & 0 & 3 \\
\hline & (2.5) & & (1.33) & (1.85) & (1) & & (2) \\
\hline \multirow[t]{2}{*}{ Katznelson et al. } & 0 & 0 & 0 & 1 & 0 & 0 & 1 \\
\hline & & & & (1) & & & (2) \\
\hline \multirow[t]{2}{*}{ Kernell et al. } & 0 & 0 & 9 & 9 & 8 & 0 & 2 \\
\hline & & & (2) & (2) & (2) & & (1) \\
\hline \multirow[t]{2}{*}{ Losco and Baker } & 1 & 0 & 3 & 13 & 9 & 1 & 2 \\
\hline & (2) & & (1.67) & (1.77) & (2) & (3) & (2.5) \\
\hline \multirow[t]{2}{*}{ Lowi et al. } & 0 & 0 & 13 & 5 & 10 & 2 & 2 \\
\hline & & & (1.92) & (1.6) & (1.9) & (1) & (2) \\
\hline \multirow[t]{2}{*}{ Magleby and Light } & 1 & 0 & 14 & 15 & 7 & 0 & 8 \\
\hline & (2) & & (1.64) & (2) & (2) & & (3) \\
\hline \multirow[t]{2}{*}{ Miroff et al. } & 0 & 0 & 4 & 14 & 0 & 0 & 3 \\
\hline & & & (1.5) & (1.93) & & & (2.7) \\
\hline \multirow[t]{2}{*}{ O'Connor et al. } & 1 & 1 & 13 & 31 & 9 & 0 & 10 \\
\hline & $(2)$ & $(2)$ & $(1.85)$ & (1.74) & (2) & & (1.5) \\
\hline \multirow[t]{2}{*}{ Patterson and Halter } & 7 & 0 & 9 & 16 & 1 & 0 & 2 \\
\hline & (3) & & $(2)$ & $(2.06)$ & (2) & & (2.5) \\
\hline Schmidt et al. & 0 & 0 & 7 & 5 & 0 & 0 & 2 \\
\hline & & & $(1.86)$ & (2) & & & (2) \\
\hline
\end{tabular}




\section{Table 2}

\section{Continued}

\begin{tabular}{|c|c|c|c|c|c|c|c|}
\hline TEXTBOOKS 6 & $\begin{array}{l}\text { CÉSAR } \\
\text { CHÁVEZ }\end{array}$ & $\begin{array}{l}\text { DOLÓRES } \\
\text { HUERTA }\end{array}$ & IMMIGRATION & $\begin{array}{l}\text { HISPANIC AMERICAN, } \\
\text { LATINO/A, HISPANIC }\end{array}$ & $\begin{array}{l}\text { NATIONAL-ORIGIN } \\
\text { GROUPS }\end{array}$ & $\begin{array}{l}\text { CHICANO/BROWN } \\
\text { POWER }\end{array}$ & $\begin{array}{c}\text { ELECTED AND } \\
\text { APPOINTED } \\
\text { OFFICIALS }\end{array}$ \\
\hline \multirow[t]{2}{*}{ Shea et al } & 3 & 0 & 6 & 17 & 5 & 0 & 2 \\
\hline & (3) & & (2.17) & $(2.12)$ & (2) & & (2) \\
\hline \multirow[t]{2}{*}{ Sidlow and Henschen } & 0 & 1 & 5 & 5 & 3 & 0 & 3 \\
\hline & & (2) & (1.8) & (2) & (2) & & (1.3) \\
\hline \multirow[t]{2}{*}{ Tannahill } & 0 & 0 & 9 & 7 & 0 & 0 & 2 \\
\hline & & & (2) & (2.14) & & & (2) \\
\hline \multirow[t]{2}{*}{ Volkomer } & 0 & 0 & 2 & 2 & 0 & 0 & 0 \\
\hline & & & (2) & (1.5) & & & \\
\hline \multirow[t]{2}{*}{ Welch et al. } & 1 & 0 & 14 & 23 & 7 & 5 & 4 \\
\hline & (3) & & (1.93) & (1.83) & $(2.1)$ & $(2.2)$ & (2) \\
\hline \multirow[t]{2}{*}{ Wilson and Dilulio } & 0 & 0 & 8 & 16 & 7 & 0 & 2 \\
\hline & & & (1.63) & $(1.88)$ & $(2)$ & & (2) \\
\hline
\end{tabular}

Note: Scores in parentheses indicate whether the coverage of Latinos in the use of that key term has a negative or positive frame (scores less than 2 indicate a negative slant to the overall coverage of Latinos; scores above 2 signify a positive slant).

\section{NOTES}

We would like to thank Javier Álvarez, Amber Arriaga, Elizabeth Durán, Beatriz González, Elizabeth Guerrero, Eden Ramírez, Alejandra Terán, and Celia Vázquez for their contributions to this project. Additionally, we would like to thank María Chávez Pringle, Lisa García Bedolla, and Melissa Michelson for their helpful comments. All errors, of course, are ours.

1. Please note that while some of the texts analyzed were Texas editions, the Texas chapters were not included in the evaluation of any textbook, because they would inflate the number of Latino/a references; these texts were therefore treated as national editions by ignoring the content of those chapters.

2. A list of the key words that were used is provided in the appendix

3. We define Latino-specific content as the use of a term within a discussion pertaining explicitly to Latinos. For example, a passage that refers to a variety of racial and ethnic groups such as African Americans, Asian Americans, and Latinos would not be considered Latino-specific.

4. Although it is possible that the nomination and confirmation of Sonia Sotomayor to the U.S. Supreme Court may change this dynamic, it seems unlikely, given that the recent appointments of Janet Napolitano as Secretary of the Department of Homeland Security, Hilda Solis as Secretary of Labor, and Ken Salazar as Secretary of the Department of the Interior are largely omitted from the latest versions of currently available textbooks.

5. Titles and citations in appendix $B$.

6. Titles and citations in appendix B.

\section{REFERENCES}

Apple, Michael W., and Linda K. Christian Smith, eds. 1991. The Politics of the Textbook. New York and London: Routledge.

Carrasquillo, Angela. 1994. "A Rationale for Hispanic Representation in Instructional Materials." Journal of Educational Issues of Language Minority Students 14: $115-26$

Cruz, Bárbara C. 1994. "Stereotypes of Latin Americans Perpetuated in Secondary School History Textbooks." Latino Studies Journal 5 (1): 51-67.

_ 2002. "Don Juan and Rebels under Palm Trees: Depictions of Latin Americans in U.S. History Textbooks." Critique of Anthropology 22 (3): 323-42.

Down, Graham A. 1988. "Preface." In A Conspiracy of Good Intentions: America's Textbook Fiasco, ed. Harriet Tyson-Bernstein, iii-viii. Washington, DC: Council for Basic Education.

Hannan, Andrew. 1987. "Racism, Politics and the Curriculum." British Journal of Sociology of Education 8 (2): 119-33.
Hatcher, Richard. 1985. "On 'Education for Racial Equality'” Multiracial Education $13(1): 30-46$.

Lavariega Monforti, Jessica. 2006-2007. "Rhetoric or Meaningful Identifiers? Latina/os and Panethnicity?" Latino/a Research Review 6 (1-2): 7-32.

Lavariega Monforti, Jessica, and Melissa Michelson. 2008. "Diagnosing the Leaky Pipeline: Continuing Barriers to the Retention of Latinas and Latinos in Political Science." PS: Political Science and Politics 41 (1): 161-66.

Lavariega Monforti, Jessica, and Lisa García Bedolla. 2009. "Policy Positions and Partisanship among Mexican and Cuban Origin Populations in the United States." In The Changing Face of America: Politics of Race, Ethnicity and Religion in Multicultural America, ed. Valerie Martinez-Ebers and Manochehr Dorraj, 138-52. New York: Oxford University Press.

National Association of Hispanic Journalists. 2006. Network Brownout Report: The Portrayal of Latinos and Latino issues on Network Television News. Washington, DC: National Association of Hispanic Journalists.

Novkov, Julie, and Charles Gossett. 2007. "Survey of Textbooks for Teaching Introduction to U.S. Politics: (How) Do They See Us? PS: Political Science and Politics $40(2): 393-98$

O'Connor, Karen, Larry J. Sabato, Gary A. Keith, and Stefan D. Haag. 2009. American Government: Roots and Reform. 2009 Texas ed. New York: Longman.

Parks, Kathrin. 2007. "Encountering Racism in the Ivory Towers: A Qualitative Analysis of Latino Student Experiences in Higher Education." Ph.D. diss., Texas A\&M University.

Richardson, Valerie. 2009. "School Head Fights 'ethnic chauvinism' in Arizona." Washington Times, July 29, Bo1.

Rodriguez, Joseph A., and Vicki L. Ruiz. 200o. "At Loose Ends: Twentieth-Century Latinos in Current United States History Textbooks." Journal of American History 86 (4): $1689-99$.

Sleeter, Christine E., and Carl A. Grant. 1991. "Race, Class, Gender, and Disability in Current Textbooks." In The Politics of the Textbook, ed. Michael W. Apple and Linda K. Christian-Smith, 78-110. New York: Routledge.

Torres, Zahira. 2009. "State Board to Keep César Chávez and Thurgood Marshall in Its Curriculum." El Paso Times, September 18. http://www.elpasotimes.com/ education/ci_13362953

Tyson-Bernstein, Harriet. 1988. A Conspiracy of Good Intentions: America's Textbook Fiasco. Washington, DC: Council for Basic Education.

Wallace, Sherri L., and Marcus D. Allen. 2008. "Survey of African American Portrayal in Introductory Textbooks in American Government/Politics: A Report of the APSA Standing Committee on the Status of Blacks in the Profession." PS: Political Science and Politics 41 (1): 153-60. 


\section{APPENDIX A: Key Words}

\begin{tabular}{|c|c|c|}
\hline Alberto Gonzáles & ethnicity/ethnic group & National Hispanic Caucus of State Legislators \\
\hline American GI Forum & Federico Peña & national origin \\
\hline amnesty & gerrymandering/racial gerrymandering & National Council of La Raza \\
\hline Antonio Villaraigosa & Henry Cisneros & Puerto Rican Legal Defense \& Education Fund \\
\hline bilingual & Hernández v. Texas & Puerto Rican \\
\hline Bill Richardson & Hilda Solis & Puerto Rico \\
\hline Bracero Program & Hispanic & racial discrimination/racism/ethnocentrism \\
\hline Brown Berets & Hispanic American & Redistricting \\
\hline Central American & $\begin{array}{l}\text { immigrant(s)/illegal or undocumented } \\
\text { immigrants }\end{array}$ & Salazár brothers (Ken and John) \\
\hline César Chávez & immigration/migration/chain migration & Salvatierra v. Del Rio ISD 1930 \\
\hline Chicano Power/Brown Power Movement & Janet Napolitano & Sánchez sisters (Loretta and Linda) \\
\hline Chicano/a & José Ángel Gutiérrez & Segregation \\
\hline Civil Rights Movement & La Raza Unida & Sleepy Lagoon \\
\hline Congressional Hispanic Caucus & LA School walkouts (1968) & South American \\
\hline CSO-Denver/Corky Gonzáles & Latin American & Spanish-speaker(s) \\
\hline Cuban American & Latino/a & United Farm Worker (UFW) \\
\hline Cuban American National Foundation (CANF) & League of United Latin American Citizens & U.S. v. López \\
\hline Delgado v. Bastrop ISD & $\begin{array}{l}\text { Mexican American Legal Defense \& Education } \\
\text { Fund }\end{array}$ & Viva Kennedy Clubs \\
\hline Dolóres Huerta & Mexican American & voting rights \\
\hline Dominican/Dominican American & minority/minority rights & Voting Rights Act of 1975 \\
\hline $\begin{array}{l}\text { English-Only legislation/policy or English as a } \\
\text { second language }\end{array}$ & Miranda v. AZ & Zoot Suit Riots \\
\hline equality/equal rights/diversity & $\begin{array}{l}\text { NALEO-National Association of Latino } \\
\text { Elected and Appointed Officials }\end{array}$ & \\
\hline
\end{tabular}


1. Barbour, Christine, and Gerald C. Wright. 2009. Keeping the Republic: Power and Citizenship in American Politics. 4th ed. Washington, DC: CQ Press.

2. Berman, Larry, and Bruce Allen Murphy. 2009. Approaching Democracy. 6th ed. Upper Saddle River, NJ: Pearson Prentice Hall.

3. Bond, Jon R., and Kevin B. Smith. 2010. The Promise and Performance of American Democracy. 9th ed. Boston: Wadsworth.

4. Coleman, John J., Kenneth M. Goldstein, and William G. Howell. 2009. Understanding American Politics and Government. New York: Longman.

5. Dautrich, Kenneth, David A. Yalof, Charldean Newell, David Prindle and Mark Shomaker. 2010. American Government: Historical, Popular and Global Perspectives. Texas ed. Boston: Wadsworth.

6. Dye, Thomas R., Bartholomew H. Sparrow, L. Tucker Gibson, Jr., and Clay Robison. 2009. Politics in America. 8th ed. Texas ed. New York: Longman.

7. Dye, Thomas, and Harmon Zeigler. 2009. The Irony of Democracy: An Uncommon Introduction to American Politics. 14th ed. Boston: Wadsworth.

8. Edwards, George, III, Martin P. Wasserberg, and Robert L. Lineberry. 2009. Government in America: People Politics and Policy. 14th ed. New York: Pearson Longman.

9. Fiorina, Morris P, Paul E. Peterson, Bertram Johnson, D. Stephen Voss, and William G. Mayer. 2008. America's New Democracy. 4th ed. New York: Pearson Longman.

10. Ginsberg, Benjamin, Theodore J. Lowi, and Margaret Weir. 2009. We the People: An Introduction to American Politics. 7th Texas ed. New York: W.W. Norton.

11. Ginsberg, Benjamin, Theodore J. Lowi, Margaret Weir, and Robert J. Spitzer. 2009. We the People: An Introduction to American Politics. Essentials Edition. New York: W.W. Norton.

12. Greenberg, Edward S., and Benjamin I. Page. 2007. America's Democratic Republic. 2nd ed. New York: Pearson Longman.

13. Harrison, Brigid Callahan, Jean Wahl Harris, Susan J. Tolchin, and Gary M. Halter. 2009. American Democracy Now. Texas ed. New York: McGraw Hill.

14. Janda, Kenneth, Jeffrey M. Berry, and Jerry Goldman. 2009. The Challenge of Democracy. 10th ed. Texas ed. Boston, MA: Houghton Mifflin Co.

15. Katznelson, Ira, Mark Kesselman, and Alan Draper. 2006. The Politics of Power: A Critical Introduction to American Government. 5th ed. Belmont, CA: Thomson Wadsworth.

16. Kernell, Samuel, Gary C. Jacobson, and Thad Kousser. 2009. The Logic of American Politics. 4th ed. Washington, DC: CQ Press.

17. Losco, Joseph, and Ralph Baker. 2009. AM GOV 2009. New York: McGraw Hill.

18. Lowi, Theodore J., Benjamin Ginsberg, and Kenneth A. Shepsle. 2009. American Government. 10th ed, 2008 Election Update. New York: W.W. Norton.

19. Magleby, David, and Paul C. Light. 2009. Government by the People. 2009 National Edition. New York: Longman.

20. Miroff, Bruce, Raymond Seidelman and Todd Swanstrom. 2007. The Democratic Debate: An Introduction to American Government. 4th ed. Boston: Houghton Mifflin.

21. O'Connor, Karen, Larry J. Sabato, Gary A. Keith, and Stefan D. Haag. 2009. American Government: Roots and Reform. 2009 Texas ed. New York: Longman.

22. Patterson, Thomas E., and Gary Halter. 2009. The American Democracy. 9th ed. Texas ed. New York: McGraw Hill.

23. Schmidt, Steffen W., Mack C. Shelley, Barbara A. Bardes, William Earl Maxwell, Ernest Crain, and Adolfo Santos. 2010. American Government \& Politics Today. 2009-2010 Texas ed. Boston: Wadsworth.

24. Shea, Daniel, Joanne Green, and Christopher Smith. 2009. Living Democracy. 2nd ed. National ed. New York: Pearson Longman.

25. Sidlow, Edward, and Beth Henschen. 2009. America at Odds. 6th ed. Belmont, CA: Wadsworth Cengage Learning.

26. Tannahill, Neal. 2010. Think American Government. New York: Longman.

27. Volkomer, Walter E. 2009. American Government. 12th ed, Election Update. New York: Longman.

28. Welch, Susan, John Gruhl, John Comer, and Susan M. Rigdon. 2010. Understanding American Government. 12th ed. Boston: Wadsworth.

29. Wilson, James Q., and John J. Dilulio. 2008. American Government: The Essentials. 11th ed. Boston: Houghton Mifflin. 